\title{
An asymptomatic pedunculated nodule on the scalp: nodular hidradenoma
}

\author{
Bezobjawowy, uszypułowany guzek na owłosionej skórze głowy - \\ guzkowy gruczolak potowy
}

\author{
Vishalakshi S. Pandit' ${ }^{\prime}$ Sanjay Desai ${ }^{2}$ \\ 'Department of Dermatology, Venereology and Leprosy, Koppal Institute of Medical Sciences, Koppal, India \\ 2Dr Desai's Clinic, Ganganagar, Behind CBI Office, Bengaluru, India \\ 'Klinika Dermatologii, Wenerologii i Trądu, Koppal Institute of Medical Sciences, Koppal, Indie \\ 2Dr Desai's Clinic, Ganganagar, Behind CBI Office, Bengaluru, India
}

Dermatol Rev/Przegl Dermatol 2018, 105, 639-642 DOI: https://doi.org/l0.5/|4/dr.2018.79177

Hidradenoma is a relatively rare tumor of appendageal origin. It is clinically characterized by a slow-growing dermal nodule and histologically by well-circumscribed dermal epithelial lobules composed of polygonal clear cells and small darker cells. Pedunculated type and ulceration are rare in hidradenoma.

Here, we report a case of a nodular hidradenoma, pedunculated variety, affecting the scalp in a male patient.

A case of 25-year-old man presented with an asymptomatic solitary nodule on the scalp. It had begun as an asymptomatic papule 1 year ago, gradually progressing to reach its present size of $1 \times 2 \mathrm{~cm}$. Occasional history of serous discharge from the nodule was noted since 3 months. On examination, a single, pedunculated, flesh-colored, non-tender, firm nodule was seen (fig. 1). The surface of the nodule was lobulated with a few crusted erosions. His general physical examination was normal. There was no regional lymphadenopathy.

Excisional biopsy was done and sent for histopathological examination. Light microscopic examination revealed a well-circumscribed tumor in the dermis showing a connection to the epidermis focally. Tumor tissue was arranged in lobules separated by fibrovascular septa (fig. 2). Within the lobules, tubular lumina of various sizes, cystic spaces and many proliferating blood vessels were noted. Individual tumor cells were round to polygonal with round to oval nuclei, fine chromatin, inconspicuous nucleoli and abundant eosinophilic to clear cytoplasm (fig. 3). Mucinous material was noted in a few cystic spaces.
Gruczolak potowy jest dość rzadkim nowotworem wywodzącym się z przydatków skóry. Klinicznie cechuje się obecnością na skórze wolno rosnącego guzka, natomiast $\mathrm{w}$ obrazie histologicznym widoczne są dobrze odgraniczone zraziki z tkanki nabłonkowej skóry zbudowane $\mathrm{z}$ wielokątnych komórek jasnych oraz mniejszych komórek o ciemniejszym zabarwieniu. Rzadko występuje postać uszypułowana gruczolaka potowego lub stwierdza się obecność owrzodzenia.

W niniejszej pracy przedstawiamy przypadek uszypułowanego guzkowego gruczolaka potowego zlokalizowanego na owłosionej skórze głowy pacjenta.

Mężczyzna 25-letni zgłosił się z pojedynczym, bezobjawowym guzkiem na owłosionej skórze głowy. Zmiana pojawiła się rok wcześniej i miała postać bezobjawowej grudki, która stopniowo powiększała rozmiary aż do wielkości $1 \times 2 \mathrm{~cm}$. W czasie 3 miesięcy poprzedzających zgłoszenie się do poradni pacjent sporadycznie obserwował występowanie wydzieliny surowiczej z guzka. W badaniu przedmiotowym stwierdzono pojedynczy, uszypułowany, twardy i niebolesny guzek barwy cielistej (ryc. 1). Powierzchnia guzka miała charakter zrazikowy, $\mathrm{z}$ nielicznymi ubytkami pokrytymi strupem. W ogólnym badaniu przedmiotowym nie wykazano żadnych nieprawidłowości. Nie stwierdzono także powiększenia regionalnych węzłów chłonnych.

Wykonano biopsję wycinającą i przesłano materiał do badania histopatologicznego. Badanie pod mikroskopem optycznym ujawniło dobrze odgraniczony guz w obrębie skóry właściwej, ogniskowo łączący się z naskórkiem. W utkaniu nowotworu stwierdzono zraziki przedzielone przegrodami włóknisto-naczy- 
Hidradenoma is a rare benign adnexal neoplasm that differentiates towards the eccrine and apocrine apparatus [1]. It is also known as nodular hidradenoma, nodulocystic hidradenoma and acrospiroma. It can occur at all ages, with female preponderance. There is no site predilection [2]. It is sub-divided into two types: apocrine (clear cell hidradenoma) and eccrine (poroid) differentiation. Clear cell hidradenoma is the most common type. Clinically it presents as a slow-growing, asymptomatic, solitary, freely mobile and firm dermal nodule. The lesions may be flesh-colored, red, blue or brown in color. Hidradenomas may be solid or cystic in varying proportions.

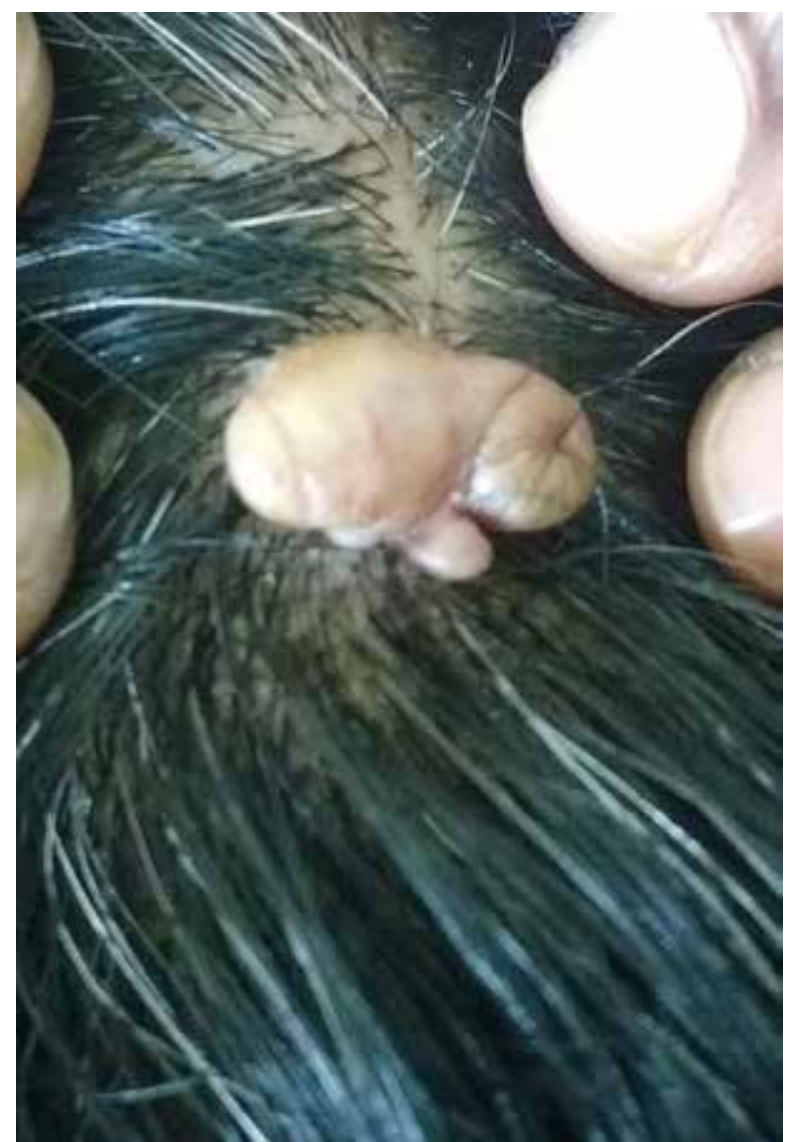

Figure I. Solitary, pedunculated, skin-colored, firm nodule in occipital region of the scalp

Rycina I. Pojedynczy, uszypułowany, twardy guzek barwy cielistej w okolicy potylicznej owłosionej skóry głowy niowymi (ryc. 2). W obrębie zrazików widoczne były struktury cewkowate o różnej wielkości, przestrzenie torbielowate oraz liczne proliferujące naczynia krwionośne. W poszczególnych komórkach nowotworowych o kształcie od okrągłego do wielokątnego stwierdzono okrągłe lub owalne jądra, drobną chromatynę, słabo widoczne jąderka oraz obfitą kwasochłonną lub przezroczystą cytoplazmę (ryc. 3). W niektórych przestrzeniach torbielowatych obecny był śluz.

Gruczolak potowy (hidradenoma) jest rzadko występującym, łagodnym nowotworem wywodzącym się z przydatków skóry, który różnicuje się na typ pochodzenia ekrynowego i apokrynowego [1]. Jest również

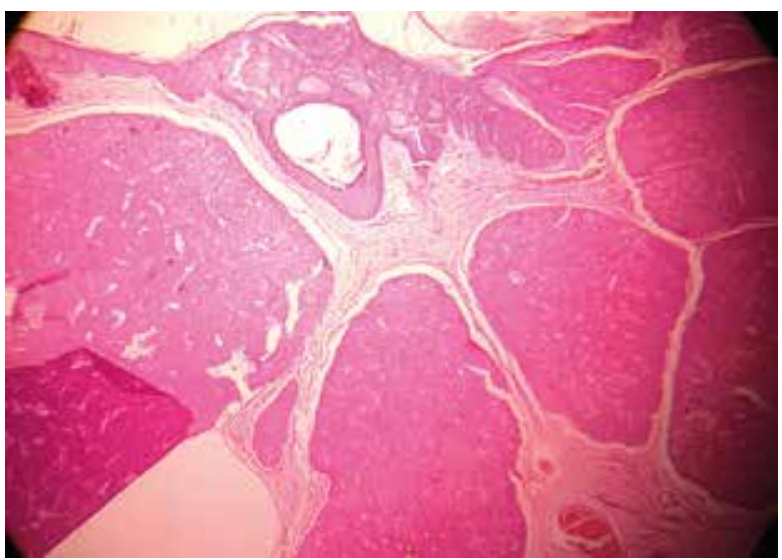

Figure 2. Tumor tissue arranged in lobules separated by fibrovascular septae and a few cystic spaces $(H+E, 10 \times)$

Rycina 2. Utkanie nowotworu z widocznymi zrazikami przedzielonymi przegrodami włóknisto-naczyniowymi oraz nielicznymi przestrzeniami torbielowatymi $(H+E, \mid 0 \times)$

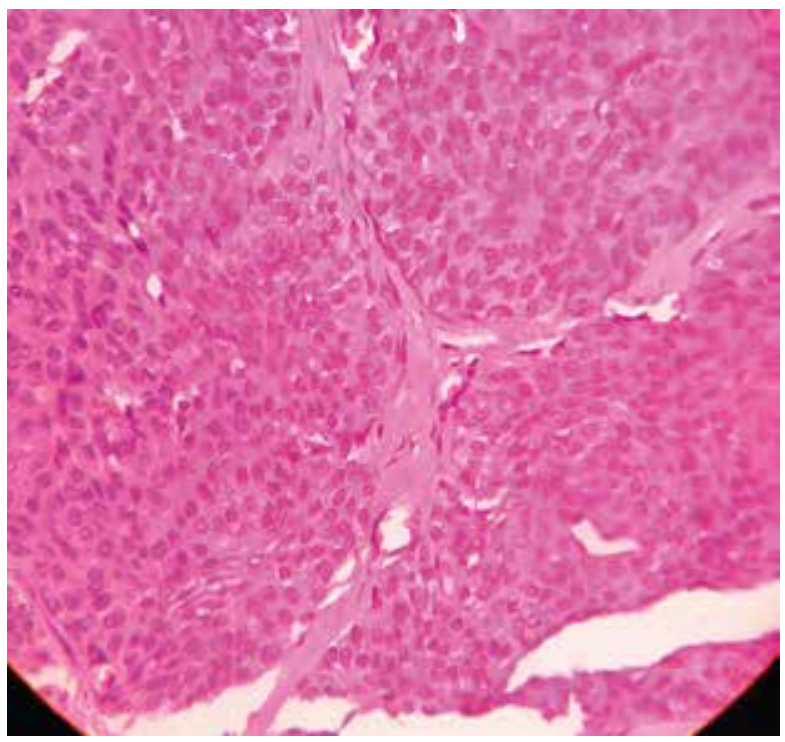

Figure 3. Tumor is composed of polyhedral cells and dark, smaller cells with eosinophilic to clear cytoplasm $(H+E, 40 x)$

Rycina 3. Guz zbudowany z komórek wielokątnych i mniejszych komórek o ciemniejszym zabarwieniu z kwasochłonną lub przezroczystą cytoplazmą $(\mathrm{H}+\mathrm{E}, 40 \times)$ 
Uncommonly they are pedunculated like the index case or ulcerated [3]. Local recurrences are common but malignant transformation is very rare [2].

Histopathologically, it is characterized by a wellcircumscribed, encapsulated nodular, solid, or solidcystic lesion in the dermis. It may be connected to the epidermis and the dermal epithelial lobules may extend into the subcutaneous fat. It is composed of two cell types - polygonal cells, whose glycogen content (periodic acid-Schiff-positive, diastase-resistant material, but no lipid) may give the cytoplasm a clear appearance; and elongated, darker and smaller cells, which may occur at the periphery. Occasionally there may be foci of squamoid differentiation with horn pearls, representing intraepidermal ductal cells. There are variable proportions of each cell type in different tumors, but clear cells predominate in less than one-third [2]. Tubular lumina of varying sizes are often present within the lobulated masses. Cuboidal or columnar cells are seen lining duct-like spaces and clefts [3].

Other cellular variants include oncocytic, epidermoid and pigmented variants with melanocytes and melanin pigment in the cells and macrophages [2]. Histologic features of poor circumscription, large size, solid sheet-like growth pattern, necrosis, and vascular and lymphatic invasion, pleomorphism, and high mitotic rate are suggestive of malignant nodular hidradenoma or hidradenocarcinoma.

Cytological features of nodular hidradenoma are a variable admixture of two types of cells: eosinophilic/polygonal and clear cells. Mild hyperchromasia, anisonucleosis and overlapping of nuclei with small distinct nucleoli are seen in clear cells, which form medium-sized small clusters. Rounded rosettelike formations and duct-like tubular structures are other features with extracellular hyaline material and amorphous material [4].

Differential diagnosis includes hemangioma, glomus tumor, cutaneous lymphoma, dermatofibrosarcoma protuberans, leiomyoma, follicular cyst, tricholemmoma and metastatic renal cell carcinoma, squamous cell carcinoma or signet ring adenocarcinoma [1]. Clinical differentiation is difficult; but characteristic histological features of clear cell hidradenoma help in differentiating it from the above conditions.

Presence of small, slit-like vascular lumina and plump endothelial cells helps in differentiating it from hemangioma [5] and presence of laminated keratin with degenerated hair shafts from the follicular cyst. Tricholemmoma shows peripheral palisading of tumor (clear) cells with the absence of cystic spaces and tubular structures [6].

Surgical removal with wide margins is recommended for this tumor as there is a high rate of local określany jako guzkowy gruczolak potowy, guzkowo-torbielowaty gruczolak potowy oraz acrospiroma. Może pojawić się w każdym wieku, częściej u kobiet. Nie ma reguły co do miejsca występowania [2]. Wyróżnia się dwa typy gruczolaka potowego: o zróżnicowaniu apokrynowym (gruczolak potowy jasnokomórkowy) i ekrynowym (poroidalnym). Najczęstszym typem jest gruczolak potowy jasnokomórkowy. Klinicznie objawia się jako pojedynczy, wolno rosnący, bezobjawowy, twardy guzek na skórze, przesuwalny wobec otaczających tkanek. Zmiany skórne mogą mieć barwę cielistą, czerwoną, niebieską lub brunatną. Guzek może mieć utkanie lite lub torbielowate $\mathrm{w}$ różnych proporcjach. Niezbyt często obserwuje się postać uszypułowaną jak w niniejszej pracy) lub owrzodzenie [3]. Często występują nawroty miejscowe, jednak bardzo rzadko guz ulega zezłośliwieniu [2].

W obrazie histopatologicznym stwierdza się dobrze odgraniczoną, otorebkowaną, guzkową, litą lub lito-torbielowatą zmianę w obrębie skóry właściwej. Zmiana może się łączyć z naskórkiem, a zraziki z tkanki nabłonkowej skóry mogą sięgać podskórnej tkanki tłuszczowej. Guzek zbudowany jest z dwóch rodzajów komórek - wielokątnych, w których zawartość glikogenu (materiału PAS-dodatniego, opornego na diastazę, lecz nie lipidowego) może nadawać cytoplazmie przezroczysty wygląd, a także mniejszych, wydłużonych komórek o ciemniejszym zabarwieniu, które mogą występować obwodowo. Sporadycznie można obserwować ogniska o zróżnicowaniu płaskonabłonkowym $\mathrm{z}$ obecnością pereł rogowych, stanowiące śródnaskórkowe komórki przewodowe. Poszczególne typy komórek mają zmienny udział w różnych nowotworach, przy czym komórki jasne dominują w mniej niż 1/3 z nich [2]. W obrębie mas zrazikowych często widoczne są różnej wielkości struktury cewkowe. Występują również sześcienne lub kolumnowe komórki wyścielające przestrzenie przewodowe i szczeliny [3].

Wyróżnia się także inne warianty komórkowe - onkocytarny, epidermoidalny i barwnikowy z obecnością melanocytów i melaniny w komórkach i makrofagach [2]. Cechy histologiczne, takie jak słabe odgraniczenie, duży rozmiar, lita budowa pozbawiona struktur cytoarchitektonicznych (sheet-like growth), martwica, inwazja naczyniowo-limfatyczna, pleomorfizm i wysoki indeks mitotyczny, wskazują na rozpoznanie złośliwego guzkowego gruczolaka potowego lub raka potowego.

W obrazie cytologicznym guzkowego gruczolaka potowego stwierdza się dwa typy komórek w zmiennych proporcjach: komórki kwasochłonne lub wielokątne oraz komórki jasne. W tworzących małe i średnie skupiska komórkach jasnych widoczna jest nieznaczna hiperchromazja, anizonukleoza oraz nakładanie się jąder komórkowych z niewielkimi, wyraźnie za- 
recurrence and silent malignant transformation [1]. Hence, follow-up of the patients is essential.

\section{CONFLICT OF INTEREST}

The authors declare no conflict of interest. znaczonymi jąderkami. Inne charakterystyczne cechy obejmują zaokrąglone formacje rozetkowe oraz przewodowe struktury cewkowe z zewnątrzkomórkową obecnością hialiny i materiału amorficznego [4].

W rozpoznaniu różnicowym należy uwzględnić takie schorzenia, jak krwiak, przyzwojak, chłoniak skóry, włókniakomięsak guzowaty skóry, mięśniak gładkokomórkowy, torbiel mieszka włosowego, osłoniak włosowy i przerzutowy rak nerkowokomórkowy, rak kolczystokomórkowy skóry oraz gruczolakorak z komórek sygnetowatych [1]. Różnicowanie kliniczne jest trudne, jednak znamienne cechy histologiczne gruczolaka potowego jasnokomórkowego pomagają w odróżnieniu go od wymienionych powyżej schorzeń.

Zwężone naczynia szczelinowate i olbrzymie komórki śródbłonka umożliwiają różnicowanie z krwiakiem [5], a obecność blaszek keratyny ze zdegenerowanymi łodygami włosów - różnicowanie z torbielą mieszka włosowego. Osłoniak włosowy cechuje się obwodowo palisadowatym układem (jasnych) komórek nowotworowych oraz brakiem przestrzeni torbielowatych i struktur cewkowych [6].

W leczeniu tego typu nowotworu zaleca się wycięcie z szerokim marginesem chirurgicznym z uwagi na dużą częstość nawrotów miejscowych oraz możliwość zezłośliwienia [1]. Z tego względu istotne znaczenie ma obserwacja pacjentów.

\section{KONFLIKT INTERESÓW}

Autorzy nie zgłaszają konfliktu interesów.

\section{References}

\section{Piśmiennictwo}

1. Gönül M., Çakmak S.K., Gül Ü., Han Ö., Karagece Ü.: A skin tumor in a young girl. Indian J Dermatol Venerol Leprol 2010, $76,445-446$

2. Weedon D.: Tumors of cutaneous appendages. Skin Pathology. $3^{\text {rd }}$ ed. Churchill Livingstone, Edinburgh, 2010, 779-793.

3. Hampton M.T., Sahn E.E.: Recurrent draining cyst on the shoulder: clear cell hidradenoma (CCH) (nodular hidradenoma). Arch Dermatol 1992, 128, 1531-1534.

4. Devanand B., Vadiraj P.: Fine needle aspiration cytology of eccrine skin adnexal tumors. J Cytol Histol 2011, 2, 129.

5. Faulhaber D., Wörle B., Trautner B., Sander C.A.: Clear cell hidradenoma in a young girl. J Am Acad Dermatol 2000, 42, 693-695.

6. Klein W., Chan E., Seykora J.T.: Tumors of the epidermal appendages. [In:] Lever's Histopathology of the skin. $9^{\text {th }}$ ed. D.E. Elder, R. Elenitsas, B.L. Johnson Jr, G.F. Murphy (eds.). Lippincott Williams and Wilkins, Philadelphia 2005, 867-926.

Received: 8.08 .2018

Accepted: 10.09 .2018

Otrzymano: 8.08.2018 r.

Zaakceptowano: $10.09 .2018 \mathrm{r}$.

How to cite this article

Pandit V.S., Desai S.: An asymptomatic pedunculated nodule on the scalp: nodular hidradenoma. Dermatol Rev/Przegl Dermatol 2018, 105, 639-642. DOI: https://doi.org/10.5114/dr.2018.79177. 